\title{
EGY KISTÉRSÉGI TÁVMUNKA STRATÉGIA BEMUTATÁSA
}

\author{
(The Introduction of the Telework Strategy of a Micro Region)
}

\section{FORGÁCS TAMÁS}

\begin{abstract}
Kulcsszavak:
távmunka munkaszervezés stratégia költségcsökkentés

A távmunka egy új munkaszervezési forma, melyet az infokommunikációs technológia fejlödése és a vállalatok globalizált müködése tett lehetővé. A távmunka lehetöséget biztosit egyes funkciók térben való tetszôleges elhelyezésére. Amennyiben egy térség egyes távmunkában végezhetö tevékenység ellátására megfelelö gazdasági környezetet biztosit, igy javithatja a térség foglalkoztatását, és töke áramolhat a térségbe. A tanulmány az erre a célra irányuló nagykátai távmunka stratégia környezetét és fontosabb elemeit tekinti át.
\end{abstract}

\section{Bevezetö}

$\mathrm{Az}$ infokommunikációs technológia fejlödésével egyre több olyan munkakör alakul át és jön létre, amelyek munkafeladatait elsősorban számítógépen kell ellátni. Ahogyan napjainkban egy üzleti folyamat munkafeladatai más-más országokban kerülnek végrehajtásra (például az egyik nemzetközi infokommunikációs nagyvállalat beszállítói számláinak fogadása Prágában, feldolgozása Budapesten, kifizetése Bécsben történik), lehetséges a munkafeladatok oly módon történő munkaszervezése is, amely lehetővé teszi a munkavégzök térben tetszőleges elhelyezkedését. Ez a környezet teszi lehetỏvé a távmunka egyre szélesebb körben való elterjedését is.

Magyarországon az Országgyülés a 2004. április 26-i ülésnapján fogadta el a 2004. évi XXVIII. törvényt, amely a hagyományos munkaviszonyra építve, a Munka Törvénykönyvébe bevezeti a távmunkavégzés fogalmát, valamint több kapcsolódó törvényt is módosít (személyi jövedelemadó, munkavédelem). Ez a szabályzás megfelel a brüsszeli távmunka keretmegállapodásban (Framework... 2002) lefektetett irányelveknek.

A 2004. évi XXVIII törvény 192/D. § definíciója a távmunkára: „A távmunkát végző munkavállaló: a munkáltató müködési körébe tartozó tevékenységet rendszeresen az általa választott, a munkáltató székhelyétől, telephelyétől elkülönült helyen, információtechnológiai és informatikai eszközzel végző és a munkavégzés eredményét elektronikus eszközzel továbbító munkavállaló.”

A KSH Gazdasági Aktivitási kérdőíve 2002 óta méri a rendszeresen és alkalmanként távmunkát végzők arányát. A távmunka definíciójaként ,Végzett-e az elmúlt 4 hétben távmunkát (informatikai és telekommunikációs eszközök igénybevételé- 
Forgács Tamás : Egy kistérségi távmunka stratégiai bemutatása

Tér és Társadalom 22. évf. 2008/2. 123-143. p.

vel)?" kérdést teszi fel. A felmérés eredményei alapjản 2005-ben a 3,9 millió foglalkoztatottból 75 ezer volt távmunkás, arányuk mintegy $2 \%$ (1. ábra).

\section{1. ÁBRA}

Távmunkások száma a KSH Gazdasági Aktivitás kérdőive alapján

(The Number of Teleworkers Based on the KSH Economic Activity Survey)

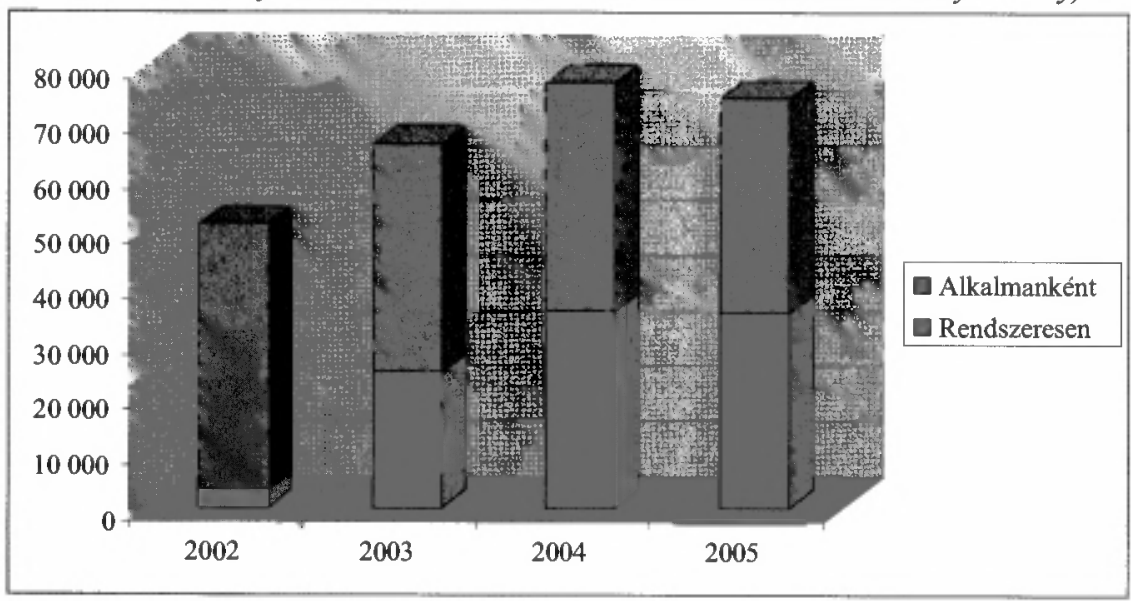

Forrás: KSH adatai alapján saját szerkesztés.

A SIBIS projekt nemzetközi felmérése alapján Magyarország elmaradása nagy az EU országaihoz és az USA-hoz képest. A 2. ábra alapján az EU15-ök átlaga 2003ban $13 \%$ volt. AZ USA-ban 2005-ben már 40millió távmunkást regisztráltak, és más országokban is dinamikus a távmunkások számának növekedése.

Az Új Magyarország Fejlesztési program (ÚMFT) Társadalmi megújulás Operatív Programjának (TÁMOP) 2. prioritása, amely az alkalmazkodóképesség javítását tüzte ki célul, „A szervezetek alkalmazkodóképességének fejlesztése” programjának leírásában így fogalmaz a távmunkáról: „A gazdasági tevékenységek átszervezése és átalakítása a teljesítmény növelése érdekében a folyamatos technológiai innováció és a globalizáció következtében a gazdaság müködésének állandó jellemzőjévé vált. Ezért szükséges a gazdasági szerkezetváltás kezelésének és elörejelzésének támogatása. (...) A változásokhoz való alkalmazkodás és a munkaeró-piaci rugalmasság és biztonság együttes erősítése jegyében támogatjuk a nem hagyományos foglalkoztatási formák, (távmunka, részmunka) elterjesztését, amennyiben az hozzájárul a foglalkoztatás növeléséhez. A vállalatok (és egyéb szervezetek) szervezeti kultúrája fejlesztésének részeként ösztönözzük az irányítási, munkaszervezési, humánerőforrás-gazdálkodási rendszerek korszerúsitését." (Társadalmi Megújulás... 2007, 88). A prioritáshoz összesen 184 milliárd forint van hozzárendelve, melynek hatására a távmunka hazai alkalmazásának jelentős javulása várható. 


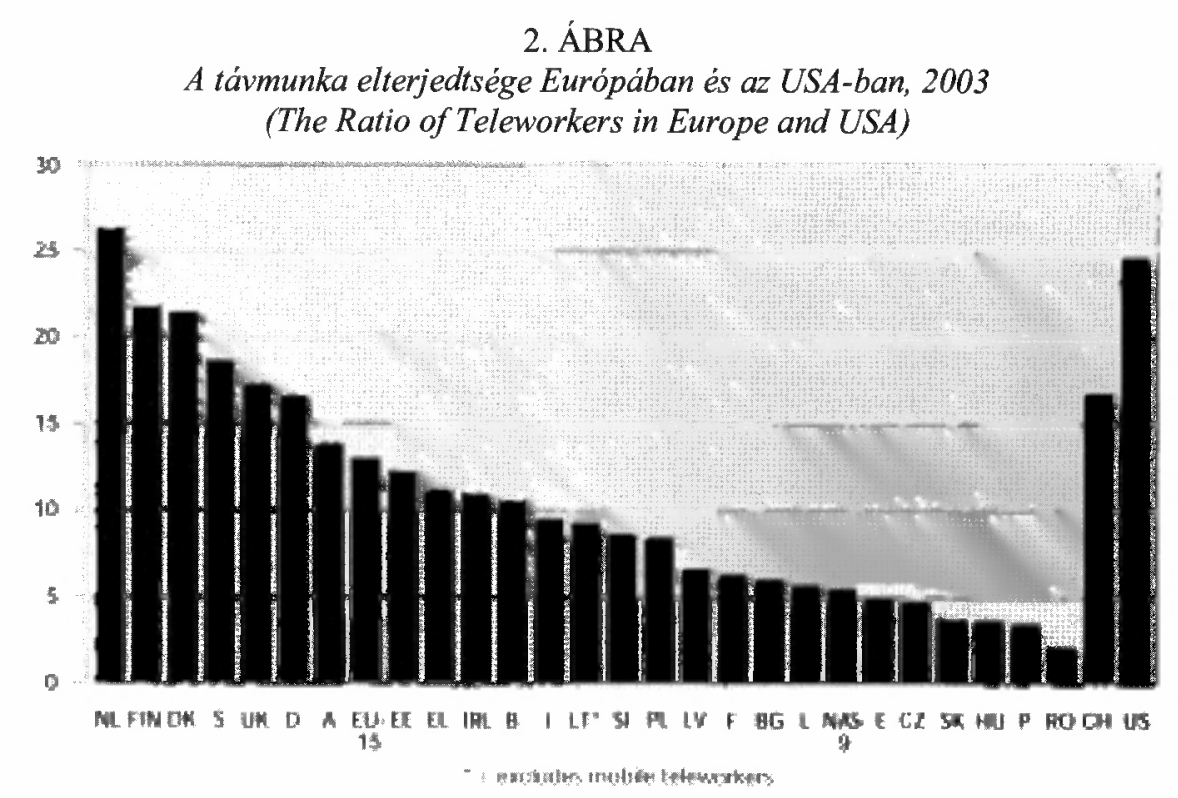

Forrás: SIBIS projekt (2006).

A távmunkának három formảját különbözteti meg a szakirodalom:

- otthoni távmunka - a munkavégző otthonából látja el feladatait (pl. programozó, adatrögzítö);

- mobil távmunka - a munkavégző otthonán és munkaadó telephelyén kívül látja el feladatait (pl. értékesítők, kárfelmérök, tanácsadók);

- távmunka-ház vagy szatellit iroda - a költségcsökkentési lehetőségek és a munkaerőpiac rendelkezésre állása alapján térségi irodákban látják el a munkavállalók a feladataikat (pl. coll-centerek, könyvelés, adatrögzítés). Ezen irodák fenntartását harmadik fél látja el (pl. önkormányzat, helyi vállalkozó).

\section{A távmunka, mint térségfejlesztési eszköz}

A távmunka lehetővé teszi egyes munkafeladatok térbeli elválasztását más munkafeladatoktól. Ilyen lehet például bármilyen adatrögzítés vagy adatfeldolgozás, illetve telefonos ügyfélszolgálat vagy kereskedelem, informatikai és grafikai tevékenységek, stb. A legtöbb tevékenység a tảvmunka több formájában is végezhető. A térbeli egyenlötlenségekből adódóan (pl. bérkülönbség, ingatlanköltségek) a távmunkaadó vállalat gazdasági előnyre tehet szert (Cost benefit.. 2006; InnoVisions... 2006).

A hagyományos foglalkoztatáshoz a távmunka-ház áll legközelebb, így ennek megvalósítása lehet a legelső lépés a vállalatoknál. A távmunka-ház ugyanis mintegy szatellit iroda funkcionál, és lehetőséget biztosít a munkaadó elöírásainak megfelelő munkakörnyezet kialakítására (pl. biztonsági követelmények, erőforrások rendelkezésre állása, logisztika). A távmunka-ház helyszínének kiválasztását önálló 
telephely-választási szempontok szerint lehet meghatározni. A müködési költségek alacsonyan tartása általános gazdasági elvárás. Az elsősorban számítógépen végezhető munkafeladatok fỏ müködési költsége a munkabér és a feladat végrehajtás helyszínének a rezsije (ingatlan, kommunikáció). A távmunka-ház fenntartásának múködési költsége elsősorban tehát a munkafeladatot ellátni képes munkavégzők bérigényéből, ingatlanköltségekböl és kommunikációs költségekből tevődik össze. Egyes adatrögzítési és adatfeldolgozási munkakörök betanítható jellege lehetővé teszi, hogy gyakorlatilag bármely alapképzettséggel rendelkező munkavállaló képes legyen a munkafeladatok megfelelő ellátására. Ezek a tényezök helyzetbe hozhatják az elmaradott kistérségeket, ahol a hagyományos foglalkoztatási módok nem teszik lehetővé a helyben foglalkoztatást.

Egy településnek vagy kistérségnek is, a távmunka révén lehetősége lehet annak ellenére növelni foglalkoztatási mutatóit, hogy ott a "hagyományos” telephelyválasztási szempontok alapján nem lenne előnyös a gazdasági környezet (pl. rossz közlekedési, gazdasági, oktatási viszonyok). A távmunkás foglalkoztatás során a béreken keresztül tỏke és tudás áramolhat a régióba. A tőke a helyi vállalkozások bevételét növelheti, a tudás pedig javithatja a helyben lakók elhelyezkedési és vállalkozási esélyeit. A távmunka által tehát az egész térség gazdasági és foglalkoztatási versenyképessége javulhat. A lehetséges hatások makrogazdasági modelljét az alábbi ábra szemlélteti (3. ábra).

\section{3. ÁBRA}

Távmunka hatásainak makrogazdasági modellje

(The Macroeconomic Modell of the Effects of Telework)

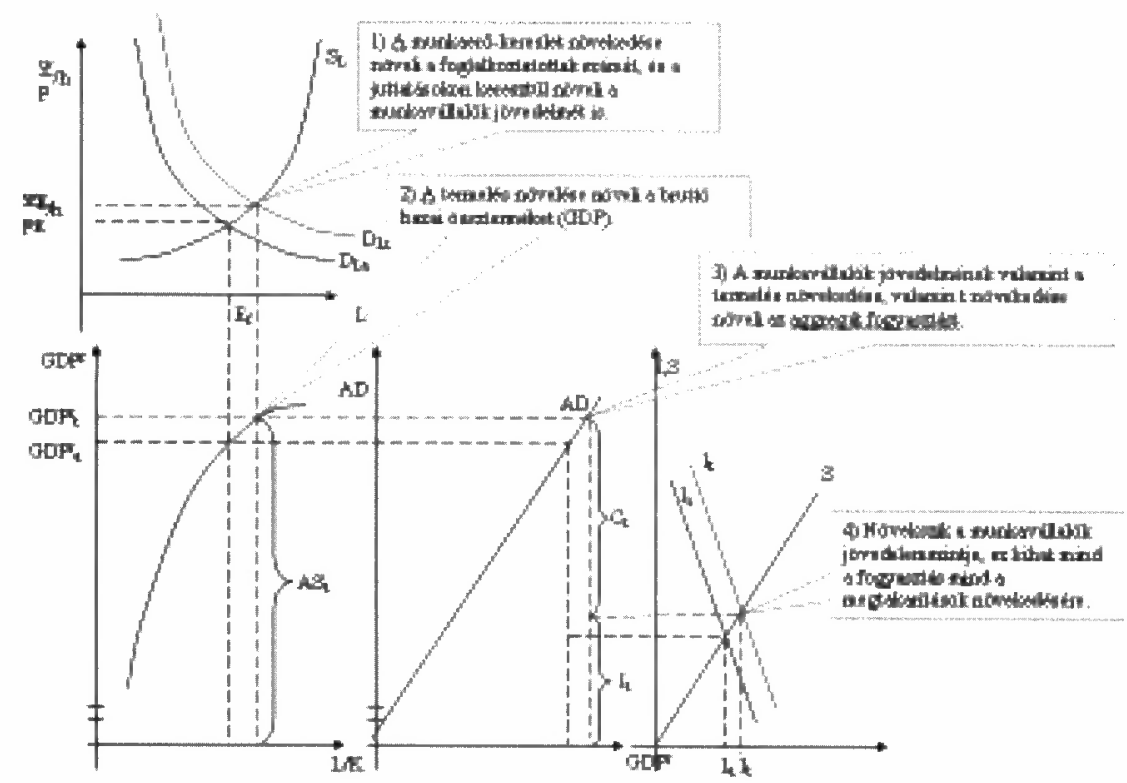

Forrás: Oroszi (2005) alapján saját szerkesztés. 
A 3. ábrán a „t” alsó index-szel jelöltük a makrogazdasági modellben a távmunkával kapcsolatos beruházások során indukált elmozdulás. Kiindulási állapotként a bal felsö 1) grafikonon jelöljük a megnövekedett foglalkoztatás elmozdulását. A 2) grafikonon látható, hogy a beruházások által, a megnövekedett munkaerövel termelt többlettel, továbbá a bérek hatására javul a térség gazdasági versenyképessége, továbbá nö a bruttó hazai össztermék (GDP). A helyi foglalkoztatás növekedésével növekszik a térségben kifizetett bérek összege, ez kihat az aggregát kereslet növekedésére is, amelyet a 3) grafikon szemléltet. A nem fogyasztásra forditott többletjövedelmet a 4) grafikonon ábrázolt összefüggés alapján a munkavállalók megtakaríthatják, ezzel növelve a lakossági megtakaritások összegét.

Tehát ezzel az új foglalkoztatási formával növelni lehet a térségben élők foglalkoztatottságát, csökkenteni a térség gazdasági és szociális elmaradottságát, és javítani a kistérség versenyképességét is.

Egy kistérség számára tehát kitörési pont lehet valamilyen távmunka térségbe vonzása. Stratégia alakítható ki a távmunka térségbe „csábítására” vonatkozóan.

2005 és 2006 során Tápió-vidéken egy kutatás és stratégiakészítés zajlott. A stratégiakészités első lépéseként Helyzetelemzés készült, amely feldolgozta a középmagyarországi, valamint a kistérségi kapcsolódó koncepciókat, stratégiákat, irányelveket. A helyzetelemzés a távmunka regionális és kistérségi SWOT elemzésével, problémafával és célfával zárult. Erre építve került kidolgozásra a Stratégia, amely figyelembe vette az európai, az országos és a kistérségi stratégiákat, célkitüzéseket, irányelveket. A stratégia céljaira és prioritásaira építkezve készülttek el az Operatív Program projektjei és ajánlásai, amelyek konkrét lépéseket tartalmaznak, és mintegy akciótervként szolgálnak a kistérségi távmunka stratégia megvalósításához. A projekt során egy Partneri Hálózat jött létre, amely feladata a stratégia megvalósítása az operatív program végrehajtása által.

Jelen tanulmány a projekt ezen lépéseit tekinti át.

\section{Helyzetelemzés}

\section{Tápió-vidék helyzetelemzése}

Tápió-vidék több szempontból is sajátos helyet foglal el a kistérségi rendszerben (4. ábra). A Kistérség föbb jellemzöi:

- Budapest közelsége meghatározó a térség számára. A külső és belső körülmények megfelelö alakulása esetén ez a kistérség is szerves része lehet Budapest tágabb agglomerációjának, melynek feltétele a tỏke, a munkaerő, az áru és az információ zavartalan áramlásának megteremtése.

- A térségre az eltartó-képesség alacsony szintje jellemzö. A helyi munkaeröpiac egyoldalú, a munkavállalók jelentős része ingázóvá vált (Budapestre, valamint Szolnokra, Újszászra, Jászberénybe). 
- Gyenge színvonalú a közlekedési összeköttetés (vasúti-közúti hálózat, tömegközlekedés) a külső központokkal, elsősorban Budapesttel, és kedvezőtlenek a térségen belüli közúti kapcsolatok is, rossz minőségúek a belső utak.

- A helyi önkormányzatok eddig kis sikerrel tudtak külső beruházókat vonzani a térségbe. Ugyanakkor a helyi gazdaság saját erőből nem képes a munkaerőpiaci feszültségeket oldani.

- A térség erős rurális jegyeket, falusias karaktert hordoz. Önmeghatározásában a „kis Hortobágy” és a „Pest megye Nyírsége” kifejezések jelennek meg. A térség sajátos migrációs problémája, hogy a Budapestről az agglomerációba kitelepülö alacsony státuszú népesség egyik célterülete.

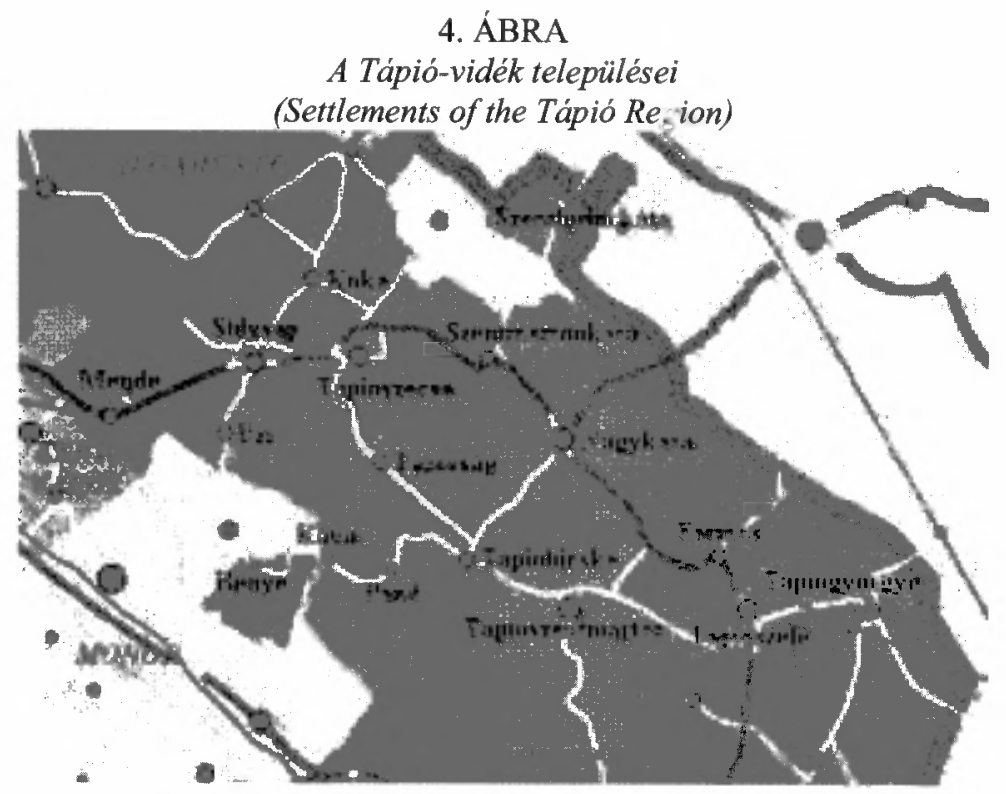

Forrás: Forgács-Pötzl et al (2006).

A Tápió-vidék Pest megye keleti-délkeleti részén helyezkedik el, a legközelebbi pontja Budapest közvetlen közelében található (Budapesti agglomeráció), míg a térség másik vége egészen Jász-Nagykun-Szolnok megye határáig (Alföld) nyúlik. A kistérség nem alkot homogén természetföldrajzi egységet, érinti ugyanakkor a dombvidéki jellegủ Gödöllői-, valamint a Monor-irsai dombság egy részét, valamint az Alföld sík jellegủ tájegységeket is.

A Tápió-vidék vizsgálatánál a nagykátai kistérség 13 településével dolgozunk, ezek: Farmos, Kóka, Nagykáta, Pánd, Szentlórinckáta, Szentmártonkáta, Tápióbicske, Tápiógyörgye, Tápióság, Tápiószecső, Tápiószele, Tápiószentmárton, Tóalmás. A 13 településböl egy város (Nagykáta), a többi föleg 2000 és 4999 fö közötti lakosságszámú település (1. táblázat). 
Forgács Tamás : Egy kistérségi távmunka stratégiai bemutatása

Tér és Társadalom 22. évf. 2008/2. 123-143. p.

TÉT XXII. évf. 2008 『 2

Gyors ténykép

129

\section{TÁBLÁZAT}

A kistérség településeinek területe és lakossága

(The Area and Population of the Micro Region)

\begin{tabular}{clcc}
\hline $\begin{array}{c}\text { Sor- } \\
\text { szám }\end{array}$ & Település megnevezése & Terület $\left(\mathrm{km}^{2}\right)$ & Lakónépesség száma (fö) \\
\hline 1 & Farmos & 40,12 & 3649 \\
2 & Kóka & 44,36 & 4323 \\
3 & Nagykáta & 81,61 & 13108 \\
4 & Pánd & 22,21 & 2038 \\
5 & Szentlőrinckáta & 20,15 & 1935 \\
6 & Szentmártonkáta & 52,19 & 4885 \\
7 & Tápióbicske & 48,48 & 3434 \\
8 & Tápiógyörgye & 53,31 & 3789 \\
9 & Tápióság & 33,54 & 2711 \\
10 & Tápiószecső & 38,38 & 6415 \\
11 & Tápiószele & 36,99 & 6049 \\
12 & Tápiószentmárton & 104,45 & 5474 \\
13 & Tóalmás & 39,34 & 3363 \\
\hline Öszesen & 615,13 & 61173 \\
\hline
\end{tabular}

Forrás: Forgács-Pötzl et al (2006).

A Tápió-vidék közúti közlekedés szempontjából autópálya-hiányos helyzetben van, az M3-as és M5-ös autópályák szögfelezöjében levő térség Budapestről a viszonylag rossz állapotú 31 . számú fớtról, vagy annak mellékútvonalain keresztül közelíthetö meg. A közúti megközelíthetőséget segíti a 4. számú országos fơútvonal közelsége. A legközelebbi település távolsága Budapesttől közel $30 \mathrm{~km}$ (Tápiószecső), a legtávolabbi közel 90 km (Tápiógyörgye). A közeli városok közül Budapest, Szolnok, Cegléd, Jászberény és Abony emelhetö ki.

A vasút a Tápió-vidék településeinek egy részét (Tápiószecső, Szentmártonkáta, Nagykáta, Farmos, Tápiószele és Tápiógyörgye) közvetlenül Budapesttel és Szolnokkal köti össze Ưjszászon keresztül (Budapest-Szolnok-Ứjszász viszonylat). A többi telepưlés átszállással közelíthetỏ meg.

A helyben lakó munkavállalók 53,8\%-a ingázik, a keresök 44\%-a naponta jár Budapestre dolgozni, további 7-8\%-uk más külső munkaerőpiacon - Szolnok, Jászberény, Monor - talált munkát.

A térség adottságai nem kedveznek igazán az új vállalkozások idevonzásának, megtelepedésének. A térségben az egyéni vállalkozások száma duplája a társas vállalkozásokénak. Az 1000 före vetített müködő társas vállalkozások száma Pest megyében 41, a Közép-magyarországi régióban 26, a kistérségben csupán 17. Az 1040 társas vállalkozásból csupán 13 foglalkoztat 50 fönél többet, és 1 vállalat alkalmaz több mint 250 fớt (2. táblázat). 


\section{TÁBLÁZAT}

Müködö társas vállalkozások megoszlása a foglalkoztatottak száma szerint (The Spread of the Companies Based on the Employment)

\begin{tabular}{|c|c|c|c|c|c|c|c|}
\hline & \multirow{3}{*}{$\begin{array}{c}\text { Mủködó } \\
\text { társas } \\
\text { vállalko- } \\
\text { zások szá- } \\
\text { ma }\end{array}$} & \multicolumn{6}{|c|}{ Ebböl } \\
\hline & & $\begin{array}{c}0 \text { és } \\
\text { isme- } \\
\text { retlen }\end{array}$ & $1-9$ & $10-19$ & $20-49$ & $50-249$ & $\begin{array}{c}250 \text { és } \\
\text { több }\end{array}$ \\
\hline & & \multicolumn{6}{|c|}{ föt foglalkoztató } \\
\hline $\begin{array}{l}\text { Nagykátai } \\
\text { kistérség }\end{array}$ & 1040 & 337 & 617 & 50 & 22 & 13 & 1 \\
\hline $\begin{array}{l}1000 \text { lakos- } \\
\text { ra vetítve }\end{array}$ & 17 & 5,5 & 10.1 & 0.8 & 0,36 & 0,21 & 0,016 \\
\hline $\begin{array}{l}\text { Pest megye } \\
\text { összesen }\end{array}$ & 47014 & 16585 & 27320 & 1694 & 930 & 414 & 71 \\
\hline $\begin{array}{l}1000 \text { lakos- } \\
\text { ra vetítve }\end{array}$ & 41 & 14,7 & 24.3 & 1.5 & 0,83 & 0,37 & 0,06 \\
\hline
\end{tabular}

Forrás: Forgács-Pötzl et al (2006).

A Tápió mente népességének iskolai végzettsége, szakképzettsége, illetve az itt élő diplomások aránya Pest megyei összehasonlításban az egyik legkedvezőtlenebb, a Ceglédi és Szobi kistérség mellett. A nagykátai térségben 2005-ben az 1715 regisztrált munkanélküli fele $(50,5 \%)$ középfokú végzettséggel rendelkezett, a felsőfokú végzettségúek száma 2004-röl 2005-re 64\%-kal emelkedett. A regisztrált munkanélküliek mintegy ötöde (17,1\%) szellemi munkakörből kerül ki, és ez a szám növekszik. Legnagyobb arányban a 17-45 év közötti korosztályból (67,3\%) kerülnek ki, és jellemzően 1 évnél kevesebb ideje vannak ebben a státuszban $(82,7 \%)$.

\section{Közép-magyarországi régió helyzetelemzése}

A Nagykátai kistérség a Közép-magyarországi régióban helyezkedik el (5. ábra). A régió az ország gazdaságilag legfejlettebb régiója. A régióban koncentrálódik az országban bejegyzett külföldi tőke több mint $62 \%$-a, a regisztrált vállalkozások $40 \%$-a, valamint a foglalkoztatottak $30 \%$-a, és itt valósult meg a beruházások mintegy fele. A gazdasági szerkezetre az előrehaladott tercierizáció jellemző. A szolgáltatások részesedése a foglalkoztatásban Budapesten $79 \%$, Pest megyében az országos átlaghoz közeli $(60,3 \%)$.

A Közép-magyarországi régióban képződik a magyarországi GDP mintegy $45,6 \%$-a, azonban a régión belül erős területi egyenlőtlenség mutatkozik: az itt koncentrálódó gazdasági potenciál a föváros meghatározó szerepére vezethető vissza.

2003-ban Budapest 41\%-kal, Pest megye 8\%-kal részesedett a magyarországi beruházásokból. A beruházások gazdasági ágak szerinti megoszlásában különösen magas Budapest részesedése a pénzügyi tevékenységek (84\%), illetve a szállitás, a 
távközlés $(60 \%)$, a közigazgatás $(65 \%)$, a szálláshely-szolgáltatás, vendéglátás $(55 \%)$ és a kereskedelem-javítás ( $40 \%$, Pest megye $20 \%$ ) területén.

\section{5. ÁBRA}

A Közép-magyarországi régió

(The Telework Capability of the Sales and Informatic Types of Work)

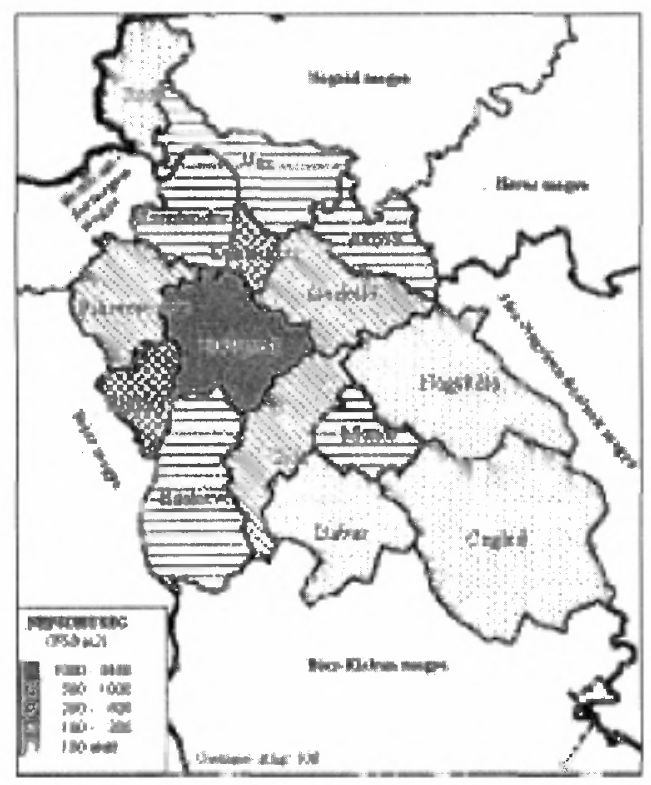

Forrás: Forgács-Pötzl et al (2006).

A régióban lévő 34 nagy cégközpont közül 28 Budapesten, 4 Budaörsön (Metro, Spar, Tesco, Pannon GSM) és 1 Fóton (Phoenix Pharma), 1 Törökbálinton (Cora) található (3. táblázat).

\section{TÁBLÁZAT}

A régió vállalatai iparági megoszlásban

(The Regions Companies as Per Industry Type)

\begin{tabular}{ll}
\hline & \multicolumn{1}{c}{ Közép-magyarországi régió } \\
\hline Feldolgozóipar & GE, Richter Gedeon, British American Tobacco, \\
Energiaellátás & Samsung, IBM, Solectron (6) \\
& Elmú, Fögáz, MVM, E.ON (4) \\
& MOL, OMV, Panrusgáz, Shell, \\
Kereskedelem & Opel Southeast Europe, Porshe Hungária, \\
& Hungaropharma, Phoenix Pharma, Metro, Spar, Tesco, \\
& Auchan, Cora, Plus, Unilever (15) \\
& Matáv, Pannon GSM, T-Mobile, Vodafone \\
Egyéb szolgáltatás & MÁV, Malév, Magyar Posta, \\
& Szerencsejáték Rt., Strabag (9) \\
\hline
\end{tabular}

Forrás: Figyelö Top 200; Hoppenstedt Bonnier (2004). 
Forgács Tamás : Egy kistérségi távmunka stratégiai bemutatása

Tér és Társadalom 22. évf. 2008/2. 123-143. p.

\section{6. ÁBRA}

Értékesitési és informatikai munkakörök távmunkásithatósága

(The Telework Capability of the Sales and Informatic Types of Work)
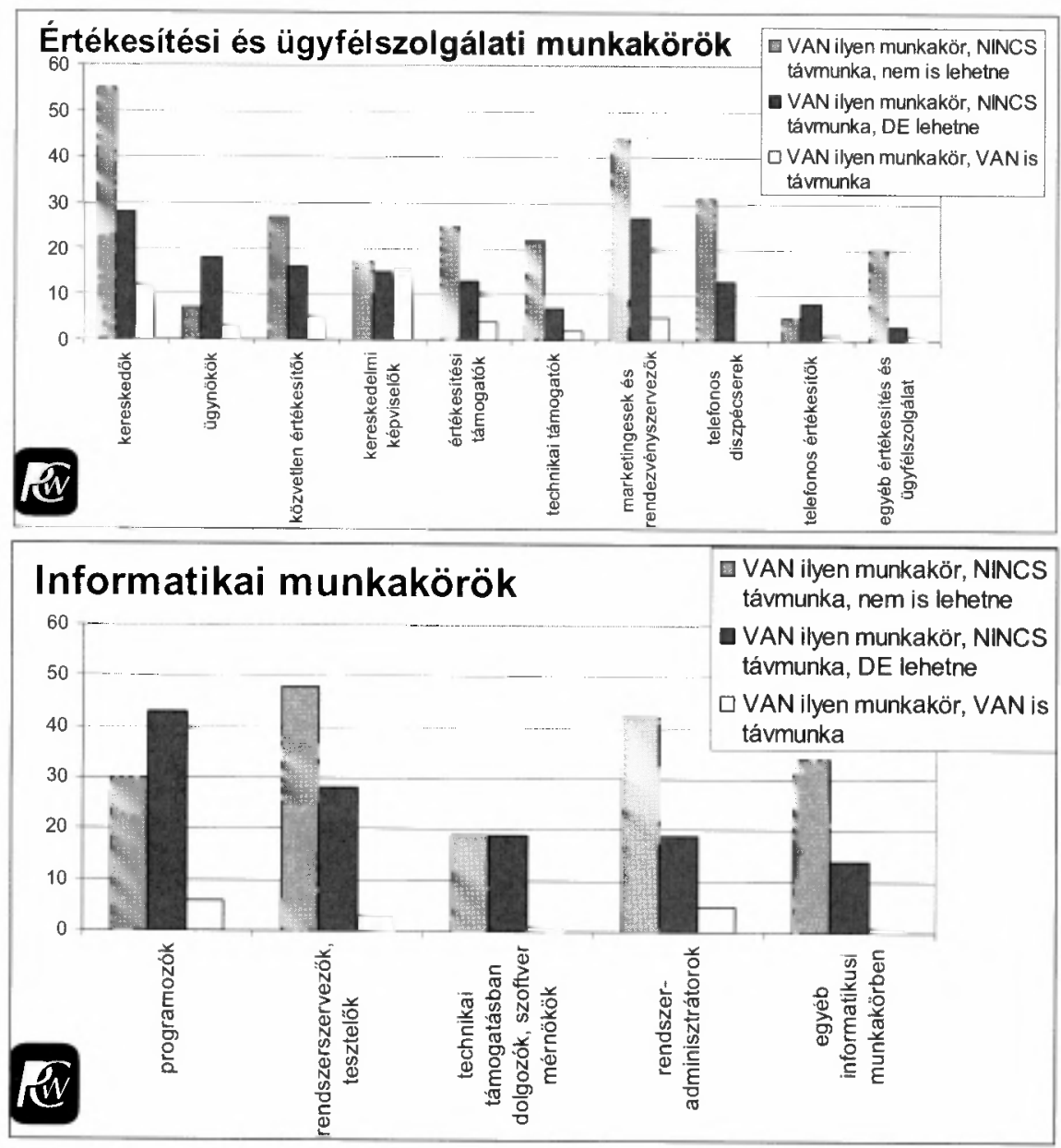

Forrás: Távmunka felmérés (2005).

Budapest informatikai szektor részesedése országos szinten kiemelkedő: a fövárosban koncentrálódik az Internet felhasználók és a domain szerverek 70\%-a, a számítógépek 50\%-a. A GKI Gazdaságkutató Rt., T-Mobile Magyarország Rt. és a Sun Microsystems Magyarország Kft. közös országos felmérése szerint a legalább 5 alkalmazottal rendelkező vállalatok körében $77 \%$-os az Internet hozzáférés, ezen belül a középvállalkozások esetében a hozzáférés $90 \%$-os. A szélessávú hozzáférések elöretörése mellett még mindig meghatározó az ISDN szerepe (37\%), de hasonló súlyú a DSL szolgáltatást igénybevevő cégek aránya is. Az Internet kapcsolattal rendelkező vállalatok 20\%-a használta az Internetet vásárlásra, míg 16\%-uk értékesítésre. A vizsgált cégcsoport 45\%-ának van honlapja (összes cég 32\%). 
A PricewaterhouseCoopers nem reprezentatív felmérése 2005. július-augusztus hónapban készült 157 Pest megyei vállalat megkérdezésével. A válaszokat ügyvezetó igazgatók (18\%), gazdasági vezetők (30\%) és HR vezetök (52\%) adták. A kutatásban részt vevő vállalatok elsősorban kiterjedt értékesítői hálózattal, pénzügyi tevékenységgel, informatikai szolgáltatásokkal rendelkező cégek. A felmérés szerint a távmunkában is végezhető munkakörök többségében alkalmazzák a távmunkát, és további tartalékok is vannak (6. ábra).

„A HR helyzete Közép-Európában” (2005) felmérés szerint Magyarországon a vállalatok $20 \%$-a alkalmazza a távmunka valamely formáját.

\section{A kistérség távmunka helyzetének SWOT elemzése}

A helyzetelemzés eredményei alapján egy SWOT elemzés segítségével került megvizsgálásra a távmunka nagykátai kistérségben való alkalmazásának lehetősége. Erösségek:

- Budapest és a nagyvárosok közelsége (Szolnok, Monor, Jászberény), ahol nagyobb, távmunkában is foglalkoztató/foglalkoztatható cégek találhatók.

- Elkészült a kistérség informatikai, gazdaságfejlesztési és e-közigazgatási stratégiája.

- Szélessávú Internet elérés képességének biztosítása minden településen.

- A megkérdezett munkaadók pozitív megítélése a távmunkával kapcsolatban: nem költségesebb a hagyományos munkavégzésnél és rugalmasabb időbeosztást tesz lehetővé.

- A megkérdezett távmunkásokat foglalkoztatók többsége további távmunkahelyek létrehozását tervezi.

- A távmunkára vonatkozó támogatásban részesülő munkaadók fenn kivánják tartani a távmunkahelyeket a támogatás lejárta után is.

- Jelentős pályázati források hívhatók le a távmunka kialakításának támogatására.

- A válaszadók többsége a távmunkával kapcsolatos információk birtokában szívesen dolgozna távmunkában.

- A munkavállalók többsége nyitott olyan képzésekre, amelyek révén nagyobb eséllyel helyezkedhetnek el távmunkában.

\section{Lehetöségek:}

- Távmunka-házak létrehozásával egyes munkafeladatok térségbe vonzása.

- A térségben élő magasan kvalifikált szakemberek otthoni távmunka végzéssel történő foglalkoztatása.

- A térséget ellátó kereskedők mobil távmunkában történő foglalkoztatása.

- A meglévő stratégiáknak (informatikai, e-közigazgatás) köszönhetően a kistérség lehetöséget kap az információs társadalom fejlesztéseire.

- Jelentős azoknak a közintézményeknek a száma, ahol biztosított az infokommunikációs eszközökhöz való lakossági hozzáférés. 
- Nemzetközi távmunka révén adminisztratív, betanítható munkakörök távmunkában való ellátása az EU fejlettebb országainak vállalkozásai részére.

Gyengeségek:

- Jellemzően alulképzettek települnek be a térségbe, a magasan képzettek pedig elvándorolnak (fỏvárosba, nagyobb városokba).

- Kevés a távmunkásítható munkaterület a térségben.

- Kistérség-fóváros viszonylatban a közlekedési feltételek nem kielégítőek.

- A távmunkáról való ismeretek hiányosak munkaadói részröl.

- A távmunkáról való ismeretek hiányosak munkavállalói részről.

- A lakosság informatikai képzettsége hiányos.

- Nem ismertek az adózási, infrastrukturális és jogi feltételek a távmunka kapcsán.

- Felkészültség hiánya munkaadói oldalról.

- Felkészültség hiánya munkavállalói oldalról.

- Piacképes szakképzések hiánya.

- Nagyfokú kilátástalanság jellemzi a helyi munkavállalók attitúdjét.

- A gazdasági társaságok Internet ellátottsága, illetve azok minősége elégtelen.

- Távmunkát ösztönző helyi támogatások hiánya.

- Nincs információ az ingázó munkavállalók összetételérỏl (végzettség, munkavégzés, munkaadó).

Veszélyek:

- Az ellenőrizhetőség nehézsége és a hazai jó példák hiánya nem kelt bizalmat a távmunka iránt munkaadói oldalról.

- A szakmailag képzett munkaerő ingázik, elvándorol.

\section{Stratégia}

A Távmunka stratégia egyaránt figyelembe veszi a globális és európai fejlődési trendeket, nem kevésbé a hazai trendeket, valamint a kistérség jelenlegi állapotát, belső lehetőségeit és elképzeléseit.

A nagykátai kistérség hosszú távú (2020-ig szóló) stratégiája az, hogy megfeleló alapot teremtsen arra, hogy a távmunka, mint eszköz, növelje a helyi foglalkoztatottságot, csökkentse a térség gazdasági és szociális elmaradottságát más kistérségekhez képest, ezáltal növelve a versenyképességet.

Cél a távmunka kistérségi elterjesztését célzó mintaértékủ foglalkoztatási stratégia kialakítása, ennek során az érintettek és érdekeltek partnerségi hálózatának létrehozatala a hátrányos helyzetủ nagykátai kistérségben.

A középtávú célkitüzések rendszere a 2013-ig terjedỏ időszak átfogó céljait (beavatkozási területeit) öleli fel. Nem elég a munkavállalókat és a munkaadókat felkészíteni a távmunkára, hanem a távmunka hátterét biztositó tényezőket is vizsgálni szükséges. Ehhez elengedhetetlen egyrészt a kistérség intelligens fejlesztése, másrészt egy olyan információhálózat létrehozása, amely elősegíti a munkaeröpiac 
mind keresleti, mind kínálati oldalának megfelelő tájékoztatását a távmunka hatékonyabb müködéséről.

\section{1. célkitüzés: Megfelelő információáramlás}

Sok vállalatnak nincs elég információja a távmunkás munkavégzés lehetőségeiről, úgy a költségcsökkentés, mint a környezetvédelem terén. Két-három évtizede még lehetetlen lett volna a telekommunikációs technika akkori állása miatt, hogy az emberek otthonról, vagy akár távmunka-házból végezzék a munkájukat. Sok vezető attól tart, hogy alkalmazottaik nem dolgoznának annyit, ha kikerülnének a felügyeletük alól, mint egyébként, ha ők figyelnek rájuk. A felmérések szerint a távmunkában otthon, vagy távmunka-házból dolgozók nagyobb része hatékonyabban dolgozik, mintha ugyanannyi időt a munkahelyén töltene el. A kistérségi helyzetelemzésből is kiderül, hogy a munkaadók a távmunka legfontosabb előnyének a rugalmasabb időbeosztást $(27 \%)$, az elérhető költségmegtakarítást (23\%), valamint a megtakarítható irodahelyeket (19\%) tartják. Hátrányként az ellenőrzés nehézségét (21\%), a hazai tapasztalat hiányát (20\%), valamint a munkavállalók elszigetelődésének veszélyét tartják, de nehézségként említik még a munkaszervezési nehézségeket és az adatbiztonsági problémákat is.

A munkavállalók fontos előnyként említették meg azt, hogy távoli cégnél is munkát vállalhatnak, több idöt tölthetnek a családdal, valamint szabadabb lehet munkaidő beosztásuk, de nem hisznek abban, hogy a távmunka révén könnyebben találhatnak munkát. Hátrányként leginkább a munkajogi rendezetlenséget, elszigeteltséget, informatikai problémák megoldásának nehézségét, karrierlehetőségek csökkenését és a munkaadói visszajelzés hiányát nevezték meg a válaszadók.

Nagyfokú bizalmatlanság jellemzi tehát a térség munkaadói és munkavállalói attitüdjét. Sokszor a távmunka bevezetésének és elfogadtatásának ezen félelmek az okai. Sőt, a hiányos, vagy nem megfelelő információk hátráltatják a távmunkának, mint atipikus foglalkoztatási formának az elterjedését. Ezért a munkaerőpiac keresleti és kínálati oldalának felkészítése és megfelelő tájékoztatása stratégiánk elengedhetetlen részét kell, hogy képezze.

A célkitüzés prioritásai:

1.1 prioritás: A munkavállalói oldal felkészítése.

1.2 prioritás: A munkaadói oldal felkészítése.

1.3 prioritás: A munkaadók és a munkavállalók távmunkára vonatkozó ismereteinek növelése.

\section{2. célkitüzés: Intelligens kistérségi fejlesztések}

A telekommunikációs és információtechnológiai struktúrák egységes fejlesztése a kistérségben, valamint a széles körü hozzáférés és felhasználói feltételek megteremtése a tudásalapú gazdaság infrastrukturális és társadalmi befogadásának érdekében. A hozzáférés megteremtése, a hálózatok megfeleló kapacitása és állapota sikerté- 
nyezője minden intelligens város- és településfejlesztésnek, és elemi feltétele a távmunka foglalkoztatás megteremtésének. Az „intelligens környezet” új üzleti lehetőségeket teremt a térség vállalkozói számára, vonzza a külföldi beruházókat, növeli a távmunka lehetőségét miközben új típusú szolgáltatásaival folyamatosan javítja a lakosság életminőségét.

A célkitüzés prioritásai:

2.1 prioritás: A gazdasági szereplők Internet és infokommunikációs ellátottságának javítása.

2.2 prioritás: A háztartások Internet és infokommunikációs ellátottságának növelése.

2.3 prioritás: Intelligens közösségi terek létrehozásának ösztönzése.

3. célkitưzés: Távmunkaadók számának növelése

A stratégia elsödleges célcsoportját képezik azok az akár kistérségi, akár más székhelyủ vállalkozások (pl. Budapest), amelyek konkrét távmunkaadók lehetnek a térségben új munkahelyeket teremtve azzal, hogy bizonyos munkafeladatokat távmunkában látnak el.

A célkitüzés prioritásai:

3.1 prioritás: Távmunkát ösztönző támogatások nyújtása.

3.2 prioritás: Távmunkában végezhető munkaterületek felkutatása és létrehozása a térségben.

3.3 prioritás: Ösztönözni a helyi gazdasági szereplők és a nagyvállalatok közötti kapcsolatteremtést.

\section{4. célkitüzés: Távmunkások számának növelése}

A stratégia másik kiemelt célcsoportját maguk a potenciális távmunkavállalók alkotják, a hátrányos helyzetü kistérség gyenge munkaerö-piaci helyzettel rendelkező potenciális munkavállalói (munkanélküliek, de akár mozgáskorlátozottak, romák, nök, nem megfelelő szakképzettséggel rendelkezők), akik számára megfelelö felkészítéssel a távmunka lehetősége a munkaerő-piaci integrációt és az esélyegyenlőséget biztosítja.

A célkitüzés prioritásai:

4.1 prioritás: Tudásközvetítés és fejlesztés, távoktatás.

4.2 prioritás: A szakmailag képzett munkaerő megtartása.

4.3 prioritás: A látens és regisztrált munkanélküliek körének megszólítása.

\section{Operativ Program}

$\mathrm{Az}$ Operatív Program (OP) megvalósítása során végzett tevékenységeket, és az eredmények hatásait tekintve az intézkedések 4 fázisba sorolhatók. A fázisokon túlmenően Ajánlásokat is tartalmaz az OP, amelyek egy olyan környezetett hivatottak 
biztosítani, ahol az egyes fázisok projektjei nagyobb eredménnyel kerülhetnek végrehajtásra. Az Ajánlások végrehajtása a legtöbb esetben közigazgatási feladat (7. ábra).

\section{7. ÁBRA}

Az Operatív Program intézkedései

(Directives of the Operative Program)

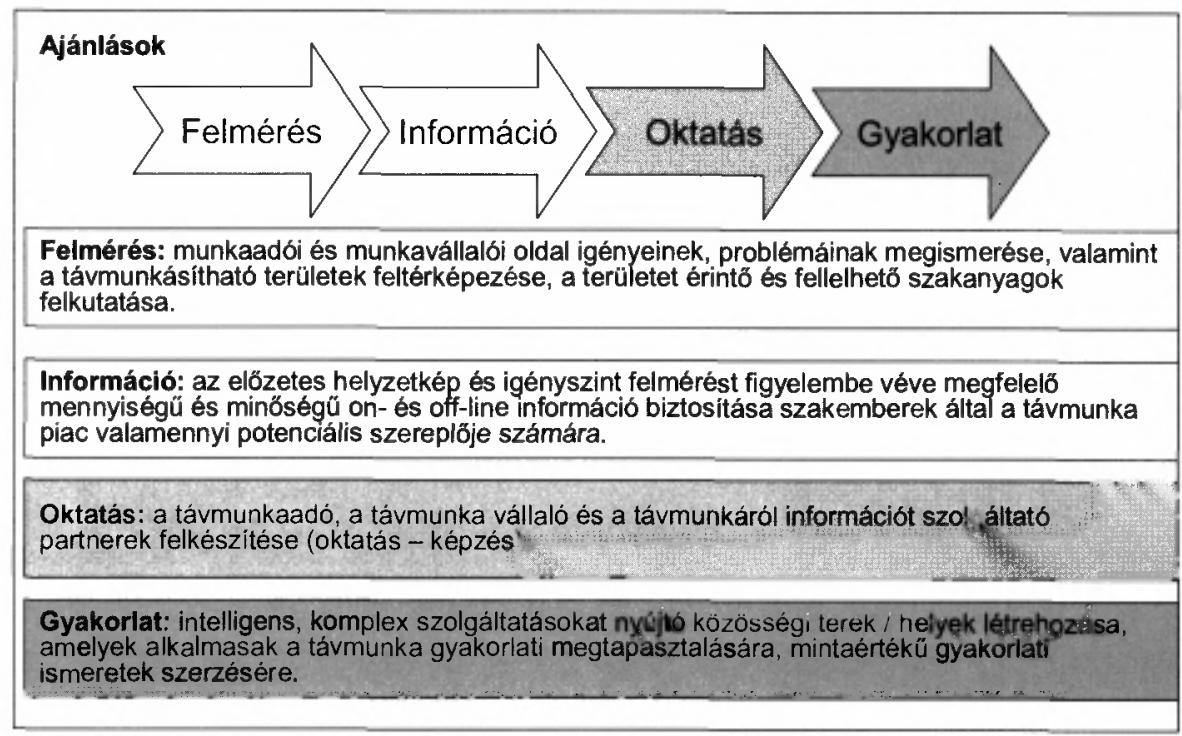

Forrás: Forgács-Pötzl et al (2006) alapján saját szerkesztés.

\section{Felmérés fázis}

A munkaadói és munkavállalói oldal igényeinek, problémáinak megismerése, valamint a távmunkásítható területek feltérképezése, a területet érintő és fellelhetó szakanyagok felkutatása.

A fázis projektjei:

\section{Munkaadói felmérés}

A munkaadói felmérés célja, megismerni a térség vállalatainak attitüdjét, igényeit, valamint a lehetséges távmunkásítható munkaköröket. A felmérés a térségen kívüli, potenciális távmunkáltatók körére is kiterjed, elsősorban a budapesti és Budapest környéki vállalatokra.

\section{Munkavállalói felmérés}

A munkavállalói felmérés célja, hogy megismerjük a térség munkavállalóinak attitúdjét, igényeit, valamint a lehetséges távmunkásítható munkaköröket. A felmérés eredményeképp határozhatók meg azok az oktatási igények, amelyek a munkavállalói lehetőségeket képesek áttranszformálni a munkaadói igényekre. 


\section{Távmunka szakemberek - kapcsolatfelvétel, adatbázis készités}

A távmunka szakemberekkel való kapcsolatfelvétel és adatbázis készítés célja, hogy felkutassa azokat a térségben és környékén élö szakembereket, akik a távmunkavégzés egyes szakterületein elegendő tudással és hajlandósággal rendelkeznek információszolgáltatásra, tanácsadásra és az oktatási programokba való bevonásra. Az adatbázis készités során szakterület, rendelkezésre állási lehetőség, tapasztalat és további specifikus igények alapján kerülnének a távmunka szakemberek csoportosításra

\section{Távmunka esettanulmányok - kutatás, elemzés, rögzités}

A távmunka esettanulmányok felkutatásának célja, hogy rajtuk keresztül gyakorlatias formában ismerjék meg a vállalatvezetők a távmunkát. Az egyes esettanulmányok tudástranszferrel hozzájárulhatnak a vállalatokon belüli munkakörök távmunkásításához. Az esettanulmányok meghatározott szempontrendszer szerint (pl. munkakör, iparág, infrastrukturális igény, kommunikációs igény stb.) kerülnek csoportosításra.

\section{Információ fázis}

Az elözetes helyzetkép és igényszint felmérést figyelembe véve megfelelő menynyiségü és minőségủ on-line és off-line információ biztosítása szakemberek által a távmunka piac valamennyi potenciális szereplöje számára.

A fázis projektjei:

Távmunka Hirlevél

A Távmunka Hírlevél célja, hogy on-line kiadvánnyal rendszeresen informálja az érdeklődőket a távmunkával kapcsolatos eseményekröl, hírekről, ezen keresztül serkentse a távmunka iránti érdeklödést, elsősorban a munkavállalók körében. A hírlevél egy rendszeres (pl. havi) elektronikus hírösszefoglaló, amelyre bárki ingyenesen feliratkozhat. Elsősorban aktuális hírek, cikkek, esettanulmányok kerülnek benne összefoglalásra.

\section{Távmunka Hirek - kiadvány}

A távmunka híreket tartalmazó rendszeres off-line kiadvány célja, hogy elsősorban a munkaadók figyelmét irányítsa a távmunkára, esettanulmányokon és szakmai cikkeken keresztül növelje ismereteiket, és nyitottabbá tegye őket a távmunka alkalmazására.

Távoktatási Anyagok - információszolgáltatási célú anyagok készitése

Az új távoktatási anyagok készítésének és azok on-line elérhetöségének célja, hogy a munkaadók és távmunkások számára költséghatékonyan széles körben terjeszthetö ismeretek legyenek elérhetók.

\section{Internetes Dokumentumtár}


A dokumentumtár létrehozásának és folyamatos frissítésének célja, hogy segítse a távmunka iránt érdeklődő vállalatokat a távmunka bevezetése során fellépő dokumentációs követelményeknek való szakszerü megfelelésben, valamint szélesebb körben elérhetővé tegye a születő tanulmányokat, költségszámításokat, esettanulmányokat.

Távmunka Szakemberek - információszolgáltatási tevékenységek

A távmunka szakemberek képzési-oktatási-tanácsadási-információ-szolgáltatási tevékenységének célja, hogy a távmunka iránt érdeklődő munkaadók számára szakszerủ információkkal szolgáljanak, és ezzel segítsék elő a távmunka gyorsabb elterjedését.

\section{Távmunka Internetes Fórum}

A távmunka fórum használatával keletkező tudásbázis hasznos segítséget nyújthat a távmunka iránt érdeklődőknek. A felmerülő kérdésekre választ kaphatnak, illetve feltehetik azokat a fórumot látogatóknak, illetve szakértőknek.

Távmunka Megoldások

A távmunka megoldások egy olyan adatbázis, ahol témakörönként megtekinthetők a távmunka bevezetését elősegítỏ megoldások. Ilyenek például a hardware szolgáltatók kínálata, kommunikációs megoldások, adó és jogi tanácsadók, ingyenes szoftverek stb. A megoldások egy helyen, tematikus csoportosítással történő szerepeltetése segíti a távmunka iránt érdeklődó vállalatokat a távmunka bevezetése során kiválasztandó megoldások áttekintésében.

Távmunka Road-show

A távmunka road-show célja, hogy a térségben, valamint azon kívüli régióközpontokban szervezett work-shopok révén ráirányítsa a figyelmet a távmunkára és az általa elérhető előnyökre. A rendezvények célcsoportjai elsösorban azon munkaadók és önkormányzati szervek, akik érintettek lehetnek a távmunka bevezetésében.

\section{Távmunka Esettanulmányok}

A távmunka esettanulmányok minél szélesebb körben történő publikálásának célja, hogy a potenciális távmunkaadók tudástranszferrel, gyakorlati úton szerezzenek ismereteket arról, hogy a saját vállalatukban mely területeken és milyen megoldásokkal tudnák alkalmazni a távmunkát.

\section{Oktatás fázis}

A távmunkaadó, a távmunka vállaló és a távmunkáról információt szolgáltató partnerek felkészítése (oktatás-kẻpzés).

A fázis projektjei:

Távoktatási Anyagok - oktatási célú anyagok készitése

A távoktatási anyagok célja, hogy a munkaadók és távmunkások számára mélyebb ismeretek kerüljenek oktatásra. Vizsgamodul segítségével nyomon követhető 
egy-egy látogató ismereti szintje, ezáltal kontrollálható a regisztrált távmunka jelöltek felkészültsége.

\section{Vállalkozói Képzések}

A vállalkozói képzések célja, hogy a vállalatvezetők számára rendelkezésre álljon az a tudás, amely a távmunka bevezetéséhez és fenntartásához szükséges. Különös figyelem fordítandó a szervezési, kontrollálhatóság és adatbiztonság kérdéseire, de érintenie kell az adózási, jogi és projektmenedzsment ismereteket is.

\section{Munkavállalói Képzések}

A munkavállalói képzések célja, hogy a munkavállalókat felkészítse a távmunkában való munkavégzésre. Kiemelt figyelmet kell száni az otthoni munkavégzés során fellépỏ speciális élethelyzetekre, problémákra.

\section{Távmunka Szakemberek - oktatási tevékenységek}

A távmunka szakemberek képzésének célja, hogy a távmunkával kapcsolatos speciális ismereteket horizontálisan átlássák, és segítsék a távmunka bevezetését és fenntartását az alkalmazó vállalatoknál.

\section{Gyakorlat fázis}

Intelligens, komplex szolgáltatásokat nyújtó közösségi terek létrehozása, amelyek alkalmasak a távmunka gyakorlati megtapasztalására, mintaértékü gyakorlati ismeretek szerzésére

\section{A fázis projektjei:}

\section{Tảvmunka Állásbörze}

A távmunka állásbörze célja, hogy a távmunkát keresők ismereteit rendszerezze, valamint a távmunkát kínáló vállalatok ajánlatait összegyủjtse.

\section{Távmunka Közvetités}

A távmunka közvetítés célja, hogy aktív szerepet vállalva, a munkaügyi központokon keresztül elérje és összekapcsolja a munkaadókat és munkavállalókat. Elsösorban a távmunkában végezhető munkakörökre koncentrál.

\section{Távmunka Tanácsadás}

A távmunka tanácsadás célja, hogy megkönnyítse a vállalatok ismeretszerzését és távmunka bevezetését. A bevezetés során jelentkező komplex feladatok információs hátterét a Távmunka Szakemberek képesek ellátni

\section{Távmunka-ház}

A távmunka-ház célja, hogy a költségmegtakarításon keresztül a munkaadók ebben a hagyományos foglalkoztatáshoz hasonló, „biztonságos" formában ismerkedjenek a távmunkával. Bár a munkások még irodába járnak dolgozni, de a munkaadótól távol, ezáltal a munkaadó megismerheti a távoli munkavégzés sajátosságait, amelyet késóbb az otthoni munkavégzésre is kiterjeszthet. 


\section{E-falvak}

Az e-falvak célja, hogy részleges távmunkások számára olyan helyszínt biztosítson, ahol akár családjukkal együtt kikapcsolódhatnak (pl. wellness, uszoda stb.), de közben a munkavégzéshez szükséges feltételek is biztosítottak (pl. videokonferencia, szélessávú internet, Wi-Fi, irodai funkciók stb.).

\section{Ajánlások}

$\mathrm{Az}$ ajánlások a projektek végrehajtási környezetének kialakítására vonatkoznak, és a legtöbb esetben közigazgatási feladatok. A cél olyan optimális gazdasági környezet kialakítása, amely kellỏen motiválja a munkaadókat a térségben való távmunka megvalósítására.

Járulékkedvezmény biztositása

A munkát terhelő adó- és járulékterhek célzott csökkentése támogassa a munkaerö-piaci szempontból hátrányos helyzetú csoportok foglalkoztatását.

Internet ellátottság növelése

A gazdasági szereplők, valamint a háztartások rendelkezzenek a távmunkavégzéshez megfelelő internet-hozzáféréssel.

Adózási és jogi feltételek egyszerüsitése

Mind a munkaadók, mind a munkavállalók legyenek tisztában a távmunkához kapcsolódó, átlátható, könnyen alkalmazható adózási- és jogszabályokkal.

Eszközbeszerzések támogatása

A hátrányos helyzetủ, potenciális munkavállalók rendelkezzenek a megfelelö infokommunikációs eszközökkel.

\section{Pályázatok}

A távmunkásokat alkalmazni kívánó munkaadók számára legyenek olyan pályázati források, melyek lehívása lehetỏvé és gazdaságossá teszi számukra távmunkások alkalmazását.

\section{Hatáselemzés}

Hatáselemzéssel megvizsgálható, hogy az Operatív Program egyes projektjei milyen mértékben fedik le a stratégiai célkitüzéseket. Az egyes projektek és stratégiai célkitüzések hatását 1-3-ig terjedő skálán osztályozva az alábbi eredmény mátrixot ismerteti a kutatás (4. táblázat).

Megállapítható, hogy a stratégia Operatív Programjai leginkább a munkaadói és munkavállalói oldal felkészítését támogatják, míg legkevésbé az internet ellátottság növelését. Az Operatív Programok fázisai közül pedig a legnagyobb hatással bíró projektek az Információ fázisban találhatók. 


\section{TÁBLÁZAT}

Az Operativ Program intézkedéseinek hatásvizsgálata

(The Study of the Effectiveness of the Directives of the Operative Program)

\begin{tabular}{|c|c|c|c|c|c|c|c|c|c|c|c|c|c|}
\hline \multirow[b]{2}{*}{$\begin{array}{l}\text { A stratégia } \\
\text { prioritása- } \\
\text { inak és az } \\
\text { operativ } \\
\text { progra- } \\
\text { moknak a } \\
\text { hatás- } \\
\text { elemzése }\end{array}$} & \multicolumn{3}{|c|}{$\begin{array}{l}\text { Megfelelö információ- } \\
\text { áramlás }\end{array}$} & \multicolumn{3}{|c|}{$\begin{array}{l}\text { Intelligens kistérségi } \\
\text { fejlesztések }\end{array}$} & \multicolumn{3}{|c|}{$\begin{array}{c}\text { Távmunkaadók számának } \\
\text { növelése }\end{array}$} & \multicolumn{3}{|c|}{$\begin{array}{c}\text { Távmunkások számának } \\
\text { növelése }\end{array}$} & \\
\hline & $\begin{array}{l}\text { A } \\
\text { mun } \\
\text { kaví } \\
\text { I. } \\
\text { latidi } \\
\text { ol. } \\
\text { dal } \\
\text { fel. } \\
\text { ket. } \\
\text { szite } \\
\text { sc }\end{array}$ & $\begin{array}{c}\text { A } \\
\text { mun- } \\
\text { kaadhi } \\
\text { soldas } \\
\text { fellke } \\
\text { szitese }\end{array}$ & 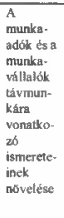 & 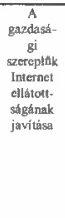 & 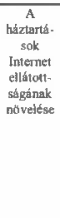 & 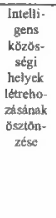 & 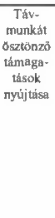 & 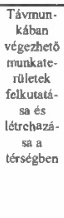 & 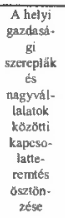 & 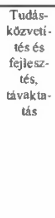 & 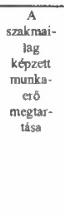 & 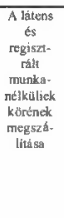 & \\
\hline Felmérés & 10 & 10 & 5 & 3 & 3 & 4 & 3 & 10 & 3 & 8 & 6 & 3 & 68 \\
\hline Információ & 9 & 10 & 12 & 0 & 0 & 6 & 2 & 5 & 7 & 10 & 4 & 6 & 71 \\
\hline Oktatás & 6 & 6 & 9 & 0 & 0 & 0 & 0 & 9 & 5 & 9 & 5 & 6 & 55 \\
\hline Gyakorlat & 2 & 2 & 3 & 0 & 0 & 6 & 0 & 6 & 4 & 0 & 6 & 6 & 35 \\
\hline Ajánlások & 9 & 9 & 0 & 9 & 9 & 10 & 10 & 2 & 6 & 0 & 10 & 2 & 76 \\
\hline & 36 & 37 & 29 & 12 & 12 & 26 & 15 & 32 & 25 & 27 & $3 I$ & 23 & \\
\hline
\end{tabular}

Forrás: Forgács-Pötzl et al (2006)

\section{Partnerhálózat}

A stratégiakészítés utolsó lépéseként egy Partnerségi Hálózat került kialakításra, melynek célja a stratégia ápolása és lebonyolítása. A Hálózat együttmúködik 18 térségi település állami, önkormányzati szervezetével, civil szerveződésekkel, társadalmi, humanitárius és gazdasági szervezetekkel, munkaadókkal és magánszemélyekkel.

Az együttmüködés célcsoportjai:

- A távmunka potenciális munkavállalói;

- A potenciális „távmunkaadó” vállalkozások (akár térségiek, akár azon kívüliek);

- A helyi fejlesztésben érintett térségi szereplők;

- A nemzeti szintủ foglalkoztatáspolitikai szervek.

A Hálózatot létrehozó vállalatok delegáltjai rendszeresen egyeztetnek az Operatív Program egyes projektjeinek megvalósíthatóságáról.

\section{Összegzés}

A távmunka az infokommunikációs technológiákra támaszkodva a munkaszervezés egy jóval költséghatékonyabb lehetőségét nyújtja a vállalatok számára. A számítógépen végzett tevékenységek ellátásának költségei (bér, ingatlan) vidéken mintegy 30-50\%-kal kedvezőbbek, mint Budapesten (Cost benefit... 2006). A távmunka tudatos felhasználása a kistérségek számára egy alternatív gazdaságfejlesztési eszközt jelenthet. A térség ugyanis a közlekedés jelentős fejlesztése és ipari központ telepítése nélkül képes javítani a foglalkoztatást. A helyi távmunka terjedése, távmunka-ház, e-falvak létrehozása erősíti a helyi munkaerőpiac helyzetét, valamint a béreken keresztül a helyi szolgáltatások iránti keresletet. Ezek a tényezők a teljes gazdasági és oktatási viszonyok javulásához vezethetnek. 
A nagykátai kistérség távmunka stratégiája egyedülálló módon tesz kísérletet a távmunka által elérhetỏ alternatív gazdaságfejlesztés megvalósítására. A stratégia és a hozzá kapcsolódó operatív program projektjei és ajánlásai egy olyan kömyezetet hivatottak megteremteni, amely a kistérséget alkalmassá teheti a távmunka bevonzására. Az EU prioritásokkal és az Új Magyarország Fejlesztési Terv célkitűzéseivel összhangban a távmunka részét képezi a gazdasági szerkezet átalakulására és az alternativ foglalkoztatási módok terjedésére megfogalmazott támogatandó céloknak. Tudatos tervezéssel, stratégiakészítéssel és a megfogalmazott projektek megvalósitásával lehetőség nyillhat az elkövetkezỏ években az elmaradott kistérségek foglalkoztatási, oktatási és gazdasági mutatóinak jelentős növelésére a távmunka révén.

\section{Irodalom}

2004. évi XXVIII törvény. (2004) Foglalkoztatáspolitikai és Munkaügyi Minisztérium, Budapest.

Cost benefit analysis of telework. (2006) CEMS-PricewaterhouseCoopers, Budapest.

Forgács T.-Pötzl V. et al (2006) A nagykátai kistérség távmunka stratégiája. Stratégiakutató Intézet Kht., Budapest.

Framework Agreement On Telework. (2002) Brüsszel.

A HR helyzete Közép-Európában. (2005) Deloitte, Budapest.

InnoVisions Conada: Studies, Stats, Facts - telework, telecommuting etc. (2006) http://www.ivc.ca/studies/index.html

Oroszi S. (2005) A munkapiac makro-környezete I-III. Elöadás vázlatok. PTE, Pécs.

SIBIS project: Statistical Indicators Benchmarking the Information Society. (2006) http://www.sibiseu.org/statistics/stat_ind.htm

Társadalmi Megújulás Operativ Program 2007-2013. (2007) A magyar köztársaság kormánya, Budapest.

Távmunka felmérés. (2005) PricewaterhouseCoopers, Budapest. 